\title{
DSC Thermal Analysis for Some Calcium Iron Arsi- Vanadate Oxide Glasses
}

\author{
AG Mostafa ${ }^{1}$, MY Hassan ${ }^{1}$ and HM Goumaa ${ }^{2 *}$ \\ ${ }^{1}$ Physics Department, Faculty of Science, AL-Zahra University, Nasr City, Cairo, EGYPT \\ ${ }^{2}$ Optical Branch, High Institute of Optics Technology, Cairo, Egypt
}

Submission: May 01, 2018; Published: May 14, 2018

*Corresponding author: HM Goumaa, Optical Branch, High Institute of Optics Technology, Cairo, Egypt, Email: h_goumaa@yahoo.com

\begin{abstract}
Glasses with molar composition of (55 - x) molpercentage $\mathrm{As}_{2} \mathrm{O}_{3}-(25+\mathrm{x})$ molpercentage $\mathrm{V}_{2} \mathrm{O}_{5}-10$ molpercentage Fe $\mathrm{O}_{3}-10$ molpercentage $\mathrm{CaO}$, where $\mathrm{x}=0,5,10,15,20,25$ and 30 , have been prepared using the normal melt quench method. The effect of replacement As $\mathrm{O}_{3}$ by $\mathrm{V}_{2} \mathrm{O}_{5}$ on the structure of these glasses have been investigated by Differential scanning calorimetric DSC thermal analysis, Density $\mathrm{d}$ measurement and Molar volume $\mathrm{V}_{\mathrm{m}}$ calculation. For each sample, DSC showed the presence of a single glass transition temperature $\mathrm{T}_{\mathrm{g}}$ in addition to two crystallization peak s. The activation energy for glass transition indicates that the prepared glasses may be of high stability. Both the density and the molar volume changed oppositely with change in composition, indicating significant change of the structural units.
\end{abstract}

Keywords: Oxide glass; DSC-Glass Transition Temperature; Iron doped glasses; Vanadate glasses; Structure

\section{Introduction}

In recent years glasses biased on $\mathrm{V}_{2} \mathrm{O}_{5}$ has attracted attention because of its potential use as cathode in solid-state devices. These glasses electrical properties classified to be similar to the n-type semiconductor. Also it was found that their electronic conduction is caused by a phonon assisted electron hopping between $\mathrm{V}^{4+}$ and $\mathrm{V}^{5+}$ ions [1-2]. Studies, on glasses containing relatively low concentration of $\mathrm{V}_{2} \mathrm{O}_{5}$, show that these glasses have a potential application as optical and electrical memory switching, cathode materials for making solid-state devices and optical fiber [1-3]. In the glasses with high percentage of $\mathrm{V}_{2} \mathrm{O}_{5}$, it is considered as a glass forming oxide [3-4]. Since the arsenic oxide $\mathrm{As}_{2} \mathrm{O}_{3}$ is consider as one of the most efficient fining agent for glass melt because of its ability for removing bubbles from glass mass [5], this article aims to characterize the glassy state of $(25+\mathrm{x})$ mole $\% \mathrm{~V}_{2} \mathrm{O}_{5}-(55-\mathrm{x})$ mole $\%$ As2 03 - 10 mole $\% \mathrm{Fe}_{2} \mathrm{O}_{3}-10$ mole $\% \mathrm{CaO}$ glass system.

Table 1: Samples composition.

\section{Experimental Work}

$(55-x)$ mol\% $\mathrm{As}_{2} \mathrm{O}_{3}-(25+\mathrm{x}) \mathrm{mol} \% \mathrm{~V}_{2} \mathrm{O}_{5}-10 \mathrm{~mol} \% \mathrm{Fe}_{2} \mathrm{O}_{3}-$ $10 \mathrm{~mol} \% \mathrm{CaO}$, glass system have been prepared, by the melt quenching, on the bases of the percentage molecular weights, as shown in Table 1 . The start materials were of purity not less than $99.98 \%$ while $\mathrm{V}_{2} \mathrm{O}_{5}, \mathrm{As}_{2} \mathrm{O}_{3}$ and $\mathrm{Fe}_{2} \mathrm{O}_{3}$ added as such and $\mathrm{CaO}$ was introduced as Calcium Carbonate. The finely mixed batches were melted in porcelain crucibles in an electric muffle furnace for 2- Hour, at temperature $750 \pm 20{ }^{\circ} \mathrm{C}$. The melts were stirred several times during melting, and they were then poured between two pre-cooled stainless steel plates in air. The thermal measurements were carried out by using Shimadzu 50-DSC Analyzer with heating rates 5, 10, 20, 30 and $40 \mathrm{~K} / \mathrm{min}$ in the temperature range $(303-1000) \mathrm{K}$. the calorimetric was calibrated for each heating rate using a material of well known melting temperature and enthalpy.

\begin{tabular}{|c|c|c|c|c|c|c|c|}
\hline Sample No. & 1 & 2 & 3 & 4 & 5 & 6 & 7 \\
\hline $\mathrm{V}_{2} \mathrm{O}_{5}$ & 25 mole $\%$ & 30 mole\% & 35 mole\% & 40 mole $\%$ & 45 mole $\%$ & 50 mole $\%$ & 55 mole $\%$ \\
\hline $\mathrm{As}_{2} \mathrm{O}_{3}$ & 55 mole $\%$ & 50 mole\% & 45 mole\% & 40 mole $\%$ & 35 mole\% & 30 mole $\%$ & 25 mole $\%$ \\
\hline $\mathrm{Fe}_{2} \mathrm{O}_{3}$ & \multicolumn{7}{|c|}{10 mole $\%$} \\
\hline $\mathrm{CaO}$ & \multicolumn{7}{|c|}{10 mole $\%$} \\
\hline
\end{tabular}




\section{Results and Discussion}

\section{DSC Thermal Analysis}

Differential scanning calorimetric DSC thermal analysis has been used in studying the thermal stability of the prepared glasses. Some parameters have been measured easily and accurately, such as the glass transition $\mathrm{T}_{\mathrm{g}}$ and crystallization $\mathrm{T}_{\mathrm{p}}$ temperatures, during different heating Processes with different rates. Figure 1 exhibits the DSC traces for sample [1] during different heating rates, $\beta=5,10,20,30$ and $40 \mathrm{~K} / \mathrm{min}$, as a representative Figure, all studied samples were showed the same shapes. For all samples, by inspecting in DSC Spectra only one glass transition temperature in addition to two overlapping exothermic crystallization peaks have been observed, for each heating rate. The crystallization peaks identified and separated by using the de-convolution method, as in Figure 2, as a representative curve, for sample (1). Two crystallization peaks appearance may be indicating that there are two different phases appearing during the crystallization process, as a result to the fact that both $\mathrm{V}_{2} \mathrm{O}_{5}$ and $\mathrm{Fe}_{2} \mathrm{O}_{3}$ act as nucleating agents [6-8]. For each sample, the appearance of one glass transition temperature may indicate high homogeneity, good glassy stare formation [9]. Table 2 exhibits the obtained thermal parameters of the studied glasses, at different heating rates. By inspecting this table, an increase in the glass transition temperature and glass crystallization temperature have been observed with the heating rate increasing. Such behavior may be indicating an increase in the thermal stability of all investigated glasses as the heating rate increase [6-10]. The dependence of the glass transition temperature $\left(\mathrm{T}_{\mathrm{g}}\right)$ on the heating rate has been studied by applying Kissinger's formula $\operatorname{Ln}\left(\mathrm{T}_{\mathrm{g}}^{2} / \beta\right)=\left(\mathrm{E}_{\mathrm{g}} / \mathrm{RT}_{\mathrm{g}}\right)+$ constant, Figure 3 Where $\Delta \mathrm{E}_{\mathrm{g}}$ is the activation energy for glass transition, $\mathrm{R}$ is the gas constant and $\beta$ is the heating rate. $\Delta \mathrm{E}_{\mathrm{g}}$ obtained from plotting $\ln \left(\mathrm{T}^{2} / \beta\right)$ against $\left(1 / \mathrm{T}_{\mathrm{g}}\right)$ which is a straight line of a slope equal $\left(\Delta \mathrm{E}_{\mathrm{g}} / \mathrm{R}\right)$, Table 3 exhibits the obtained values of $\mathrm{Eg}$ for the studied glass system. Also, Figure 3 exhibits the effect of the $\mathrm{V}_{2} \mathrm{O}_{5}$ content increment on the glass transition temperature $\left(\mathrm{T}_{\mathrm{g}}\right)$, which appears to decrease linearly as $\mathrm{V}_{2} \mathrm{O}_{5}$ content increase. Like behavior may be implies a decrease in the glass thermal stability, in other word a decrease in the rigidity of the glass network [11]. Since the unstable glasses have a loose packing, therefore it can predict an increase in the molar volume of the studied glasses as $\mathrm{V}_{2} \mathrm{O}_{5}$ content was increased.

Table 2: DSC Parameters.

\begin{tabular}{|c|c|c|c|c|c|c|c|c|}
\hline Sample No. & 1 & 2 & 3 & 4 & 5 & 6 & 7 & \\
\hline \multirow{3}{*}{$\beta=5 \mathrm{~K} / \mathrm{min}$} & $\operatorname{Tg} \mathrm{K}$ & 691 & 681 & 668 & 658 & 653 & 639 & 632 \\
\hline & Tp1 K & 757 & 745 & 733 & 727 & 723 & 721 & 715 \\
\hline & Tp2 K & 818 & 801 & 784 & 781 & 776 & 771 & 768 \\
\hline \multirow{3}{*}{$\beta=10 \mathrm{~K} / \mathrm{min}$} & $\operatorname{Tg} \mathrm{K}$ & 710 & 692 & 677 & 669 & 665 & 651 & 644 \\
\hline & Tp1 K & 769 & 756 & 742 & 738 & 735 & 733 & 762 \\
\hline & Tp2 K & 829 & 811 & 793 & 792 & 788 & 783 & 800 \\
\hline \multirow{3}{*}{$\beta=20 \mathrm{~K} / \mathrm{min}$} & $\operatorname{Tg} \mathrm{K}$ & 711 & 703 & 689 & 680 & 676 & 663 & 656 \\
\hline & Tp1 K & 780 & 767 & 754 & 750 & 747 & 746 & 725 \\
\hline & Tp2 K & 842 & 824 & 805 & 804 & 799 & 796 & 792 \\
\hline \multirow{3}{*}{$\beta=30 \mathrm{~K} / \mathrm{min}$} & $\operatorname{Tg} \mathrm{K}$ & 716 & 708 & 695 & 987 & 682 & 669 & 663 \\
\hline & Tp1 K & 785 & 773 & 761 & 757 & 753 & 752 & 732 \\
\hline & Tp2 K & 846 & 829 & 812 & 811 & 806 & 802 & 800 \\
\hline \multirow{3}{*}{$\beta=40 \mathrm{~K} / \mathrm{min}$} & $\operatorname{Tg} \mathrm{K}$ & 721 & 712 & 699 & 691 & 687 & 674 & 668 \\
\hline & $\mathrm{Tp} 1 \mathrm{~K}$ & 791 & 778 & 765 & 761 & 758 & 757 & 747 \\
\hline & Тр2 K & 852 & 834 & 816 & 815 & 811 & 807 & 805 \\
\hline
\end{tabular}

Table 3: Glass Transition activation energy.

\begin{tabular}{|c|c|c|c|c|c|c|c|}
\hline Sample & $\mathbf{1}$ & $\mathbf{2}$ & $\mathbf{3}$ & $\mathbf{4}$ & $\mathbf{5}$ & $\mathbf{6}$ & $\mathbf{7}$ \\
\hline Eg $(\mathrm{kJ} / \mathrm{mole})$ & 261 & 252 & 241 & 222 & 217 & 200 & 190 \\
\hline
\end{tabular}




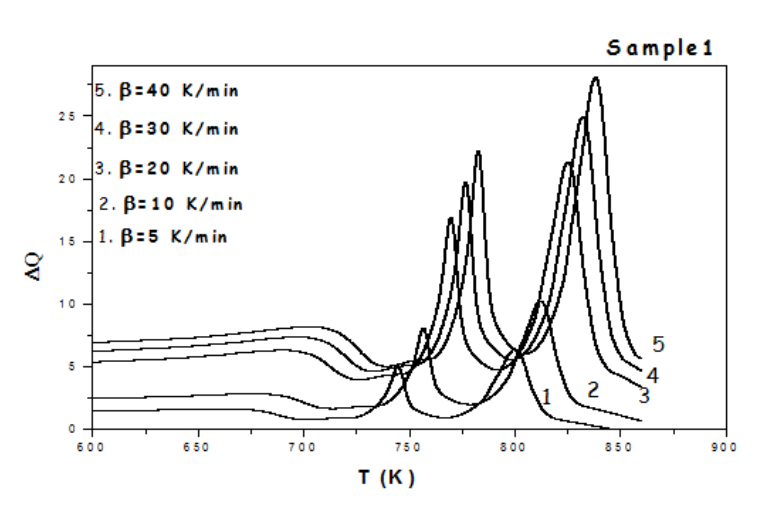

Figure 1: DSC Traces For sample (1), as a representative figure.

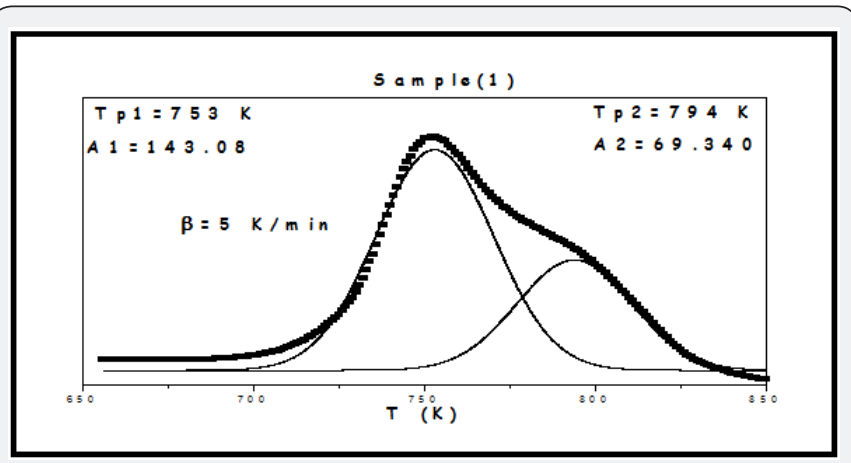

Figure 2: De-convolution of DSC of sample (1) at $\beta=5 \mathrm{~K} / \mathrm{min}$.

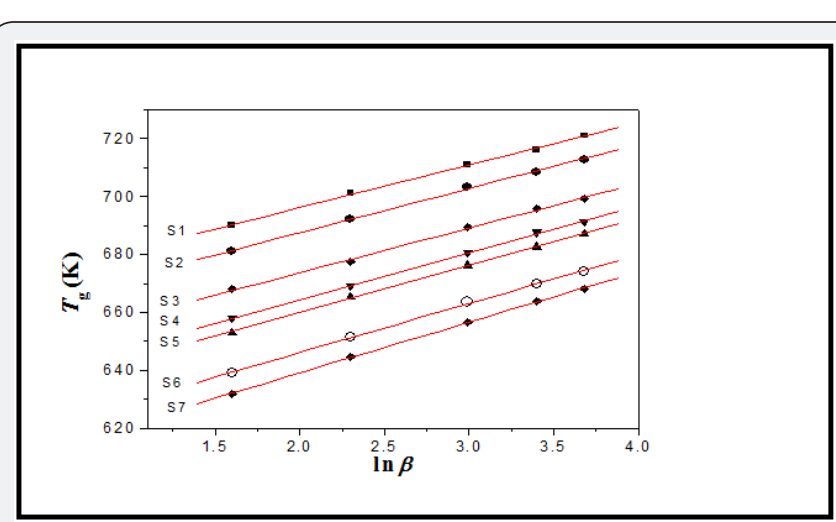

Figure 3: The dependence $\mathrm{Tg}$ on both the heating rate and the $\mathrm{V}_{2} \mathrm{O}_{5}$ content.

\section{Density ( $\rho)$ and Molar Volume (Vm)}

Density is an important and accurate property, which strongly reflects the fine changes in the glass structure. Therefore, the liquid displacement method used to obtain the room temperature experimental density of the studied glasses and plotted as a function of $\mathrm{V}_{2} \mathrm{O}_{5}$ content in Figure 4. It is clear that the measured density decreases approximately linear with $\mathrm{As}_{2} \mathrm{O}_{3}$ replacement by $\mathrm{V}_{2} \mathrm{O}_{5}$. The molar volume is directly related to the internal spatial structure of glass so it is more suitable to discuss the differences between the structures of the studied glasses in terms of the molar volume [12]. Figure 5 exhibits the calculated molar volume which appeared to increase linearly as $\mathrm{V}_{2} \mathrm{O}_{5}$ content was gradually increased, indicating a loose packed structure in an agreement with DSC results. The behavior of both density and molar volume can be attributed to the generally increase in the oxygen atoms, the increase in the non-bridging oxygen $(\mathrm{V}=0)$ atoms, in addition to the difference in the atomic weight of $\mathrm{V}^{5+}\{50\}$ and $\mathrm{As}^{3+}\{74.9\}$ cations [13]. The inversely variation of both the density and molar volume indicates significant change of the structural units with change in composition.

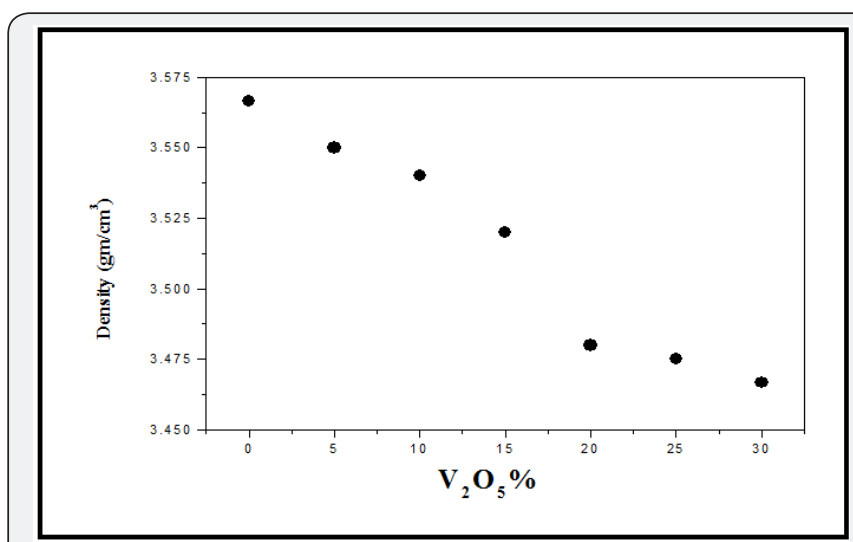

Figure 4: The effect of $\mathrm{V}_{2} \mathrm{O}_{5}$ content on studied samples densities.

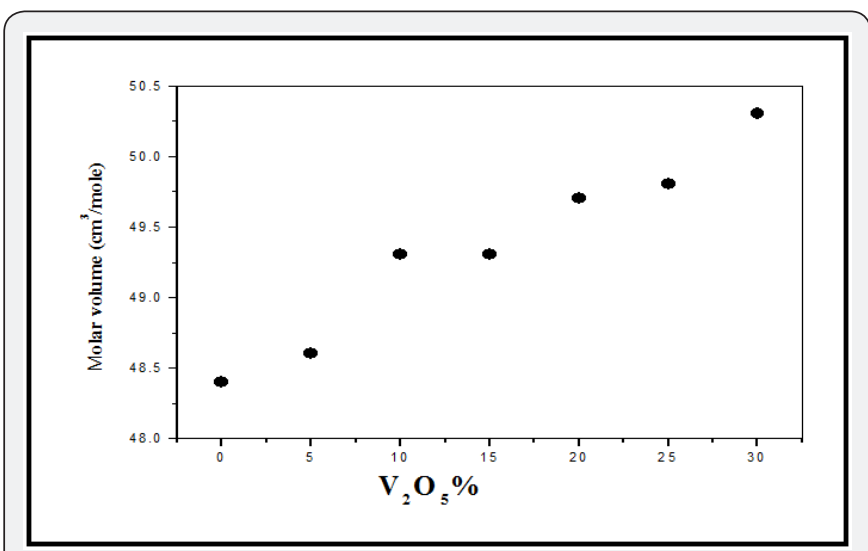

Figure 5: The effect of $\mathrm{V}_{2} \mathrm{O}_{5}$ content on the studied samples molar volume.

\section{Conclusion}

$(55-\mathrm{x}) \% \mathrm{As}_{2} \mathrm{O}_{3} \cdot(25+\mathrm{x}) \% \mathrm{~V}_{2} \mathrm{O}_{5} \cdot 10 \% \mathrm{Fe}_{2} \mathrm{O}_{3} \cdot 10 \% \mathrm{CaO}$, Where $0 \leq x \leq 30$, glass system have been studied. DSC thermal analysis showed the presence of one glass transition temperature and indicated high homogeneity of the prepared glasses. DSC Also showed the presence of two crystallization peaks indicate the existence of two different crystalline phases. The values of experimental density have found to decrease as $\mathrm{V}_{2} \mathrm{O}_{5}$ content was increased. The calculated molar volume values showed an increase, indicating a more open structure, as $\mathrm{V}_{2} \mathrm{O}_{5}$ content was increased. The inversely variation was observed for both the 
density and molar volume indicates significant change of the structural units with change in composition.

\section{References}

1. S Sindhu, S Sanghi, A Agarwal, Sonam, VP Seth (2005) The Role of $\mathrm{V}_{2} \mathrm{O}_{5}$ in the Modification of Structural, Optical and Electrical Properties of Vanadium Barium Borate Glasses. Physica B: Condensed Matter 365(14): 65-75.

2. GD Khattak, N Tabet (2004) Local structure and redox state of vanadium in strontium-vanadate glasses. J Electron Spectroscopy and Related Phenomena 36(5): 257-264.

3. S Sindhu, S Sanghi, A Agarwal, VP Seth, N Kishore (2006) Structural, optical, physical and electrical properties of $\mathrm{V}_{2} \mathrm{O}_{5} \cdot \operatorname{SrO} \cdot \mathrm{B}_{2} \mathrm{O}_{3}$ glasses. J Spectrochimica Acta Part A 64(1): 196-204.

4. A Mekki, GD Khattak, D Holland, M Chinkhota, LE Wenger (2003) Structure and magnetic properties of vanadium-sodium silicate glasses. Journal of Non-Crystalline Solids 318(1-2): 193-201.

5. Paulo Ccero do Nascimento, Denise Bohrer, Emilene Becker, Leandro Machado de Carvalho (2005) Comparison of different sample

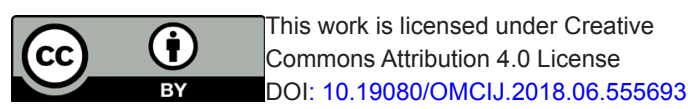

treatments for arsenic speciation in glass samples. J Non-Crystalline Solids 351(14-15): 1312-1316.

6. ER Shaaban, MT Dessouky, AM Abousehly (2007) J Physics Condensed Mater 19: 096-212.

7. ER Shaaban (2006) Non-isothermal crystallization kinetic studies on a ternary, $\mathrm{Sb}_{0.14} \mathrm{As}_{0.38} \mathrm{Se}_{0.48}$ chalcogenide semi-conducting glass. Physica B: Condensed Matter 373(2): 211-216.

8. I Kashif, H Farouk, AM Sanad, SA Aly (1992) Structural studies of some $\mathrm{V}_{2} \mathrm{O}_{5}-\mathrm{P}_{2} \mathrm{O}_{5}-\mathrm{B}_{2} \mathrm{O}_{3}-\mathrm{Fe}_{2} \mathrm{O}_{3}$ glass systems. J Material Science 27(1): 122-126.

9. BV Raghavaiah, N Veetaiah (2004) J Phys Chem of solids 65(6): 11531164.

10. NC De Souza, R Lebullenger, MCC Custodio, AC Hernandes (2000) J Non Crystalline Solids 273: 94-99.

11. A AbdEl Moneim (2002) J Materials Chem and Phys 73: 318-322.

12. V Raghavaiah, C Laxmianth, N Veeraiah (2004) J Optics Communications 235: 341-349.

13. H Mori, H Matsuno, H Sakata (2000) J Non-Crystalline Solids 276: 7894.

\section{Your next submission with Juniper Publishers will reach you the below assets}

- Quality Editorial service

- Swift Peer Review

- Reprints availability

- E-prints Service

- Manuscript Podcast for convenient understanding

- Global attainment for your research

- Manuscript accessibility in different formats

( Pdf, E-pub, Full Text, Audio)

- Unceasing customer service

Track the below URL for one-step submission https://juniperpublishers.com/online-submission.php 